\title{
EFFECT OF ENZYMATIC PREPARATIONS ON IMPROVEMENT OF ENERGY UTILIZATION IN BROILER CHICK DIETS
} 1. CANOLA MEAL

\author{
Mohammed, A.A. Abdel-Mageed; Sayed, A.M. Shabaan \\ and Mohammed, S. Bahnas \\ Animal Prod. Res. Inst., Agric. Res. Center, Ministry of Agric., Doki, Giza, Egypt. \\ Poultry Production Dept, Fac. of Agric., Fayoum Univ., Fayoum, Egypt.
}

\begin{abstract}
:
This study was conducted using 390 unsexed day-old Arbor-Acres broiler strain chicks which, individually wing-banded, weighed and randomly distributed into 13 experimental groups of similar mean body weight of 3 replicates each and aimed to study the possibility of partially replacing dietary protein with canola meal $(\mathrm{CM})$ protein with /without multicarbohydrase enzymes and its effect on growth performance, some carcass traits, some blood serum parameters and economical efficiency. An experimental corn-soybean meal starter and finisher basal diets were formulated in which dietary protein was replaced by $\mathrm{CM}$ protein at replacement ratios of $16,32,48$ and $64 \%$. Diets were formulated to be iso-nitrogenous and iso-caloric being $23 \% \mathrm{CP} \& 3000 \mathrm{kcal} \mathrm{ME} / \mathrm{kg}$ for the starter diet and 20\% CP \& $3100 \mathrm{kcal} \mathrm{ME} / \mathrm{kg}$ for the finisher diet. Thirteen dietary treatments were compared. One treatment consisted of the basal diet without CM (positive control diet). Four treatments consisted of the positive control diet supplemented with 16, 32, 48 or 64\% CM without enzyme supplementation (negative control diets). Eight additional treatments consisted of the negative control diets supplemented with either Zympex ${ }^{\circledR} 008$ or Xylam ${ }^{500}$ enzyme products at a level of $0.05 \%$. Live growth performance, carcass characteristics, some blood serum parameters, sensory evaluation of cooked meat and economical efficiency were determined. From the nutritional and economical point of view, it could be concluded that substituting CM protein up to $48 \%$ for dietary protein in both starter and finisher broiler diets supplemented with Zympex ${ }^{\circledR} 008$ enzyme product at a level of $0.05 \%$ has no detrimental effect on broiler chick's growth performance and gave the best economical efficiency.
\end{abstract}

Key words: Canola meal, performance, slaughter, carcass, blood, sensory economic, broiler.

\section{INTRODUCTION}

According to Apata and Ojo (2000), the high poultry compound feeds cost is largely derived from the exorbitant feed ingredients prices, increasing competitive demand for them by man and animals and conventional ingredients scarcity. Therefore, to reduce feed cost, which accounts for 60 to $70 \%$ of total cost (Nworgu et al., 1999; Singh, 1990 and Banerjee, 1992), research efforts are being geared towards evaluating alternative poultry feed ingredients (Igwebuike et al., 2001 and Ojewola et al., 2003). According to Atteh and Ologbenla (1993) such alternatives should have comparative nutritive value but cheaper than the conventional sources.

Canola seeds (Brassica napus, L.) were planted successfully in Egypt lands. This seasonal winter oil crop was proven to resist drought and can be planted in semi arid regions (Leela et al., 2002). Brassica Napus is the best among canola

Fayoum J. Agric. Res. \& Dev., Vol. 21, No. 2, July, 2007 
types since its component have been altered through genetic selection which markedly reduced its detrimental components, erucic acid and glucosinolates (Leeson and Summers, 2001). Canola meal (CM), a by-product of oilextraction from canola seeds which is produced in Egypt, has reasonable amounts of protein and energy and has a low price. Thus, it can serve as a cheaper plant protein source in poultry diets. However its nutritive value is limited by the presence of a number of antinutritive factors, including the indigestible nonstarch polysaccharides (NSP) (Slominski and Campbell, 1990; Bell, 1993; Castell et al., 1996 and Dale, 1996). The major NSP components found in CM is pectic polysaccharides, which include rhamnogalacturonan with associated side chains consisting of arabinose, galactose, and xylose residues (Bacic et al., 1988). These sugars can occur in short or long, complex side chains containing neutral pectic polymers, such as arabinans, galactans, or arabinogalactans (Aspinall and Cottrell, 1971; Siddiqui and Wood, 1972; Daveby and Aman, 1993). Moreover, the lower energy in CM compared to other protein sources economically limits its use in high energy broiler feeds. This highlights the opportunity for using feed enzymes in CM-based diets. The successful use of enzymes in cereal-based diets (Chesson, 1993) has stimulated interest in enzymes application to target the vegetable protein components of poultry diets. Meng et al., (2005) found that a multicarbohydrase supplement containing cell wall-degrading carbohydrase enzymes was significantly effective in depolymerizing cell wall polysaccharides of CM in vitro study.

Many attempts has been made to cut feeding cost down to the minimum levels by replacing the costly feedstuffs with relatively less expensive plant protein sources. Among the important attempts made to minimize the feeding cost is the present study which was designed to study the possibility of partially replacing dietary protein with CM protein in broiler diets supplemented with multicarbohydrase enzymes and its effect on growth performance, some carcass traits, some blood parameters, and economical efficiency.

\section{MATERIALS AND METHODS}

Experimental birds and housing

A total number of 390 unsexed day-old Arbor-Acres broiler strain chicks were individually wing-banded, weighed and randomly distributed into 13 experimental groups of similar mean body weight $(44.44 \pm 0.12 \mathrm{~g} /$ chick) of 30 chicks each, which consists of 3 replicates of 10 chicks each. Chicks were housed in galvanized wire cage batteries.

\section{Experimental diets}

An experimental corn-soybean meal starter and finisher basal diets were formulated in which dietary protein was replaced by CM protein at replacement ratios of $16,32,48$ and $64 \%$. Diets were formulated to be iso-nitrogenous and isocaloric being 23\% CP \& $3000 \mathrm{kcal} \mathrm{ME} / \mathrm{kg}$ for the starter diets and $20 \% \mathrm{CP} \& 3100$ $\mathrm{kcal} \mathrm{ME} / \mathrm{kg}$ for the finisher diets. The experimental diets were formulated to cover the recommended nutrient requirements (NRC, 1994). Dietary ME content was under recommended ME levels suggested by Arbor-Acres broiler nutrition guide. The composition and calculated chemical analysis of the experimental diets is presented in Table (1).

\section{Tested Materials}

Canola meal used in this study showed a composition of $11.5 \%$ moisture; $35 \% \mathrm{CP} ; 4 \% \mathrm{EE} ; 9.45 \% \mathrm{CF} ; 6.3 \%$ ash; $0.27 \% \mathrm{Ca} ; 0.29 \%$ avail. P; $0.63 \%$ Met.; $0.78 \%$ Cyst.; $1.78 \%$ Lys and 1833 kcal.ME. The enzymatic preparations used in

Fayoum J. Agric. Res. \& Dev., Vol. 21, No. 2, July, 2007 


\section{EFFECT OF ENZYMATIC PREPARATIONS ON IMPROVEMENT... 47}

this study were: 1) Zympex ${ }^{\circledR} 008$ which is a multi-component enzyme preparation containing $\alpha$-galactosidase, $\beta$-mannanse, protease, amylase, $\beta$ glucanase, xylanase and cellulase. It is used in legumes-rich diets (such as soy and canola meal) at a level of 500 gram Zympex ${ }^{\circledR 008}$ per ton of feed and 2) Xylam ${ }^{500}$ is an enzymatic preparation containing $\beta$-xylanase $(1260 \mathrm{U})$ and $\alpha$ amylase (8000 U). It is used at a level of 500 gram Xylam ${ }^{500}$ per ton of feed.

Experimental design and treatments

Thirteen dietary treatments were compared. One treatment consisted of the basal diet without CM (a positive control diet). Four treatments consisted of the positive control diet supplemented with 16, 32, 48 and $64 \% \mathrm{CM}$ without enzyme supplementation (negative control diets). Eight additional treatments consisted of the negative control diets supplemented with either Zympex ${ }^{\circledR 008}$ or Xylam $^{500}$ at level of $0.05 \%$.

\section{Management}

Chicks were reared under similar management conditions. Ambient temperature was maintained at $34-35^{\circ} \mathrm{C}$ during the $1^{\text {st }}$ week and weekly decreased by $5 \mathrm{C}$ for the next 3 weeks. Birds received continuous artificial lighting at night during the whole experimental period. Mash feed and fresh clean tap water were available ad liblitum.

\section{Measurements and data collection}

\section{Growth performance:}

Individual body weight (BW, g) and feed intake (FI, g/bird) were weekly recorded to determine body weight gain (BWG, g). Feed conversion ratio (FCR, $\mathrm{g}$ feed/g gain) and mortality rate (MR) \% were also calculated on weekly basis.

\section{Carcass parameters}

At the end of the experimental period (6 wks), 78 birds $(3 \hat{0}+$ $39 /$ treatment) with BW similar to the mean were slaughtered to determine carcass characteristics. Obtained criteria were dressing, eviscerated carcass and breast \%. Abdominal fat was removed from the gizzard and abdominal region and individually weighed for each carcass. Also, the internal organs (liver, heart and gizzard) were individually separated and weighed.

\section{Sensory evaluation of cooked meat}

Three carcasses from each treatment were roasted in a conventional electric oven at $160{ }^{\circ} \mathrm{C}$ and were sensory evaluated. Ten practiced judges, who showed sensitivity in discrimination, were used as instrumental tools to investigate the differences in meat quality due to different treatments. Every judge rinsed his mouth with deionized water between tasting to clear the mouth of residual stimuli and lessen adaptation effects.

Judges determined the differences in color darkness, tenderness (the forces required to compress the meat between molar teeth on the first bite force necessary to attain a given deformation), juiciness (the degree and amounts of juice of the sample released upon chewing), chewiness (the number of chews required to reduce the sample to state ready for swallowing), flavor by mouth or taste (the sensation perceived by mouth), odour by smelling the meat that presented warm in a covered-petri dish and overall acceptability of different cooked meat. 
Table 1

Fayoum J. Agric. Res. \& Dev., Vol. 21, No. 2, July, 2007 
EFFECT OF ENZYMATIC PREPARATIONS ON IMPROVEMENT... 49

Blood serum parameters

Seventy eight blood samples $(3 \hat{\delta} \& 3 q /$ treatment) were withdrawn from wing vein and serum was separated by centrifugation for 10 minutes (3000 $\mathrm{rpm}$ ) and stored in vials at $-20{ }^{\circ} \mathrm{C}$ for later analysis. Frozen serum was thawed and assayed to determine, on individual bases, some biochemical parameters in terms of total protein (TP), albumin (Alb) and triglycerides (TG) and cholesterol (Cho) by using commercial kits and Atomic Absorption Spectrophotometer, following the same steps as described by manufactures. Values were expressed as $\mathrm{mg} / 100 \mathrm{ml}$. Serum TP was measured according to Henry (1974). Globulin (Glo) was calculated by the difference between serum TP and Alb, since the fibrinogen usually comprises a negligible fraction (Sturkie, 1986). The Alb/Glo ratio was also calculated.

\section{Chemical and statistical analysis}

Experimental diets were analyzed following procedures detailed by the Association of Official Analytical Chemists (AOAC 1990) for CP, CF, DM and EE. The NFE was calculated by difference. Metabolizable energy (ME) of experimental diets was calculated considering the ME values of different feed ingredients (NRC, 1994). Canola meal was analyzed at Central Laboratory for Food and Feed (CLFF) Agri. Res. Center, Ministry of Agric., Giza, Egypt.

Obtained data were expressed as means \pm standard error and statistically analyzed by analysis of variance (ANOVA) according to Steel and Torrie (1980). Also, the General Linear Model (GLM) procedure of SPSS computer statistical program for MS Windows release 6.0 June 1993 was used. The significant means were ranked using Duncan's Range Test (Duncan, 1955) as outlined by Obi (1990). Statistical significance level was tested at probability of $\mathrm{p} \leq 0.05$.

\section{RESULTS AND DISCUSSION \\ Live growth performance:}

The results obtained for live growth performance in terms of BW, BWG, FI, FC and MR during the whole experimental period is shown in Table 2.

The initial BW of day-old broiler chicks was similar for all treatments. With regard to $\mathrm{CM}$ levels, it was noticed that feeding $16 \% \mathrm{CM}$-diets did not cause significant change in $\mathrm{BW}, \mathrm{BWG}, \mathrm{FI}, \mathrm{FCR}$ and $\mathrm{MR}$ in comparison to $0 \% \mathrm{CM}-$ diet. Similarly, Abdallah et al., (2003) reported that 25\% CM.had no effect on broilers BW and FCR. Increasing CM level over 16 to $32 \%$ significantly decreased BW, BWG and FI values and increased MR \%, the only exception was for FCR that did not significantly differ. However, increasing CM level from 32 to $48 \%$ significantly decreased BW, BWG and FI values and increased MR \%, but it did not significantly affect FCR. Feeding 64\% CM-diets gave the lowest BW, BWG and FI values and the highest MR \%. The only exception was for FCR that was similar in comparison to feeding either 32 or $48 \%$ CMdiet, but it was significantly higher than those of feeding either 0 or $16 \% \mathrm{CM}$ diet. These results are in good agreement with the findings of NewKirk and Classen (2002) who found that 100 and 80\% replacement of SBM with CM in starter and finisher broiler diets, respectively had a significant decrease in BW. Also, Abdallah et al., (2003) reported that replacing CM up to $75 \%$ of SBM had adverse effect on BW and FCR. However, the present results disagreed with those of Salmon et al., (1981) who found that CM concentration had no effect on BWG and Leeson et al., (1987) who found that CM concentration had no effect on BWG, FI and FCR. The observed decrease in FI when increasing

Fayoum J. Agric. Res. \& Dev., Vol. 21, No. 2, July, 2007 
Table 2

Fayoum J. Agric. Res. \& Dev., Vol. 21, No. 2, July, 2007 
EFFECT OF ENZYMATIC PREPARATIONS ON IMPROVEMENT... 51

$\mathrm{CM}$ may be due to phytic acid existence in CM that may reduce calcium availability or absorption and in turn decrease FI (Summers et al., 1988). Further, Summers and Bedford (1994) showed that the problem is complicated by cation-anion balance in CM-diets. This is may be due to the lower potassium content of CM (1.2\%) than SBM (1.9\%), so that the electrolyte balance level is lower in a CM compared to a SBM-based diet. In addition, the higher sulphur and phosphorus levels in CM result in an even lower positive balance of dietary cations. This suggests that increasing dietary cations levels by adding extra calcium or potassium carbonate will correct the problem. Total cation-anion balance should be considered, so that further studies are needed in this respect. Hulan and Proudfoot, (1980) noted that the inclusion of CM in caged layer diets has been associated with increased MR. However, MR was not influenced by adding CM at levels of $0,10,20$, and $26 \%$ in turkey diets from 1 day to 19 wks of age (Waibel et al., 1992). The association between the high MR \% and feeding CM was explained by Butler et al. (1982) who showed that the deaths were associated with hepatocyte degeneration, abnormalities in the biliary system and leakage of cellular enzymes into the plasma.

Regarding enzymatic preparations, Zympex ${ }^{\circledR} 008$ significantly gave the highest BW and BWG values and the best FCR. The two exceptions were for FI that did not differ due to enzyme supplementation and MR \% that significantly reached the highest in case of enzyme-free diets followed by Xylam ${ }^{500}$ supplemented diets and then Zympex ${ }^{\circledR 008}$-supplemented diets. With respect to the interaction between $\mathrm{CM}$ level and enzymatic preparations, using either Zympex $^{\circledR 008}$ or Xylam ${ }^{500}$ with $16 \% \mathrm{CM}$ diet did not exert any significant effect in BW, BWG, FI, FCR and MR as compared to the corresponding enzyme-free diets. On the other hand, supplementing Zympex ${ }^{\circledR} 008$ to diet containing 32, 48 or $64 \% \mathrm{CM}$ resulted in significant high BW, BWG and MR as well as significant improvement in FCR as compared to the corresponding Xylam ${ }^{500}$ supplemented diets that caused similar values in these respects with the corresponding enzyme-free diets. However, adding either Zympex ${ }^{\circledR} 008$ or Xylam $^{500}$ to diet containing 32,48 or $64 \% \mathrm{CM}$ diet did not cause any significant effect in FI as compared to the corresponding enzyme-free diets. The improvements in final BW, BWG and FCR when enzyme Zympex ${ }^{\circledR} 008$ was added to diet with different CM levels (32, 48 and 64\%) as compared to the control (0) within each group is in contradiction of findings of Simbaya et al., (1996) and Kocher et al., (2000, 2001) who stated that growth performance was not affected when commercial enzyme complexes containing multicarbohydrase activities were added to broiler diets containing high CM levels. The failure of enzymatic preparations to affect FI of birds in the present study is in agreement with those reported by Ghazalah et al. (1994), Vukic Vranjes and Wenk (1995), Miles et al. (1996), Marsman et al. (1997) and Ouhida et al. (2000) who found that enzymes supplementations had no significant effects on FI.

Carcass parameters and chemical composition of breast muscle:

The percentage of eviscerated carcass, dressing, breast and abdominal fat as well as the chemical composition of the breast muscle in terms of CP and EE are summarized in Table 3.

Fayoum J. Agric. Res. \& Dev., Vol. 21, No. 2, July, 2007 
Table 3

Fayoum J. Agric. Res. \& Dev., Vol. 21, No. 2, July, 2007 
EFFECT OF ENZYMATIC PREPARATIONS ON IMPROVEMENT... 53

With regard to CM levels, it was noticed that feeding 16\% CM-diets did not cause significant change in both carcass parameters and chemical composition of breast muscle in comparison to 0\% CM-diet. Increasing CM level from 16 to $32 \%$ significantly decreased both carcass parameters and chemical composition of breast muscle, the only exception was for EE that did not significantly differ. However, there was no significant response obtained for increasing CM level from 32 to $48 \%$ in both carcass parameters and chemical composition of breast muscle except for dressing \% that was significantly decreased and abdominal fat $\%$ that was significantly increased. Feeding 64\% CM-diets gave the lowest carcass parameters and chemical composition of breast muscle values except for abdominal fat and EE that reached the highest values. The current results are not in line with the findings of Waibel et al., (1992) who stated that using CM up to $26 \%$ had no effect on breast yield, Franzoi et al., (2000) who found that carcass protein increased and carcass fat decreased linearly with the CM amount and Abdallah et al., (2003) who showed that CM-supplemented diets had no effect on dressing and carcass \%. However, these results are in accordance with the last authors in regard to abdominal fat $\%$.

Regarding enzymatic preparations, Zympex ${ }^{\circledR} 008$ significantly gave the highest carcass parameters values except for abdominal fat that reached the lowest value. On the other hand, there was no significant response obtained for enzyme supplementation in chemical composition of breast muscle.

With respect to the interaction between $\mathrm{CM}$ level and enzymatic preparations, using either Zympex ${ }^{\circledR} 008$ or Xylam ${ }^{500}$ with $16 \% \mathrm{CM}$ diet did not exert any significant effect in both carcass parameters and chemical composition of breast muscle as compared to the corresponding Xylam ${ }^{500}$ supplemented diets that caused similar values in these respects with the corresponding enzyme-free diets. However, supplementing Zympex ${ }^{\circledR} 008$ to diet containing 32, 48 or $64 \%$ CM resulted in significant higher eviscerated carcass, dressing and breast meat as well as significant lower abdominal fat as compared to the corresponding Xylam ${ }^{500}$ - supplemented diets that caused similar values in these respects with the corresponding enzyme-free diets. On the other hand, adding either Zympex ${ }^{\circledR 008}$ or Xylam ${ }^{500}$ to diet containing 32,48 or $64 \% \mathrm{CM}$ diet did not cause any significant effect in chemical composition of breast muscle as compared to the corresponding enzyme-free diets.

Generally, CM contains seed hulls, concave particles, which have a tendency to stick to the inside of the digestive tract. From a technological point of view, if the gastrointestinal tract is torn during processing, then the black canola hulls can stick to the carcass causing it to be downgraded. The solution is to exclude $\mathrm{CM}$ from the feed during the last 5 days before market.

\section{Edible giblets:}

The percentage of edible giblets in terms of liver, heart, gizzard and total edible giblets are given in Table 4. There was no significant response obtained for CM levels, enzyme supplementation or the interaction between CM level and enzymatic preparations in gizzard \%.

With respect to $\mathrm{CM}$ levels, it was noticed that feeding $16 \% \mathrm{CM}$-diets did not cause significant change in edible giblets in comparison to $0 \% \mathrm{CM}$-diet. Increasing CM level from 16 to 32 or 48 to $64 \%$ significantly decreased liver, heart and total edible giblets. However, increasing CM level from 32 to $48 \%$ did not exert significant effect in liver, heart and total edible giblets.

Concerning enzymatic preparations, Zympex ${ }^{\circledR 008}$ significantly gave the highest liver, heart and total edible giblets \%.

Fayoum J. Agric. Res. \& Dev., Vol. 21, No. 2, July, 2007 
With respect to the interaction between $\mathrm{CM}$ level and enzymatic preparations, using either Zympex ${ }^{\circledR} 008$ or Xylam ${ }^{500}$ with $16 \% \mathrm{CM}$ diet did not exert any significant effect in edible giblets as compared to the corresponding enzyme-free diets. However, supplementing Zympex ${ }^{\circledR 008}$ to diet containing 32, 48 or $64 \% \mathrm{CM}$ resulted in significant higher liver, heart and total edible giblets $\%$ as compared to the corresponding Xylam ${ }^{500}$-supplemented diets that caused similar values in these respects with the corresponding enzyme-free diets.

Table (4): Edible giblets of broiler chicks fed different dietary treatments at $42 \mathrm{~d}$ of age

\begin{tabular}{|c|c|c|c|c|c|c|}
\hline \multicolumn{3}{|c|}{ Treatments } & \multicolumn{4}{|c|}{ Edible giblets (\% of live BW) } \\
\hline $\begin{array}{l}\text { CM } \\
(\%)\end{array}$ & $\begin{array}{c}\text { Zympex }^{\circledR 008} \\
(\%)\end{array}$ & $\begin{array}{c}\text { Xylam }_{(\%)}^{500} \\
\end{array}$ & Liver & Heart & Gizzard & Total \\
\hline 0 & $\mathbf{0}$ & $\mathbf{0}$ & $3.30 \pm 0.05^{\mathrm{a}}$ & $0.75 \pm 0.02^{\mathrm{a}}$ & $2.53 \pm 0.02$ & $6.58 \pm 0.12^{\mathrm{a}}$ \\
\hline \multirow{3}{*}{16} & $\mathbf{0}$ & $\mathbf{0}$ & $3.34 \pm 0.04^{\mathrm{a}}$ & $0.72 \pm 0.03^{\mathrm{a}}$ & $2.51 \pm 0.01$ & $6.57 \pm 0.12^{\mathrm{a}}$ \\
\hline & 0.05 & $\mathbf{0}$ & $3.31 \pm 0.02^{\mathrm{a}}$ & $0.73 \pm 0.01^{\mathrm{a}}$ & $2.51 \pm 0.03$ & $6.55 \pm 0.14^{\mathrm{a}}$ \\
\hline & $\mathbf{0}$ & 0.05 & $3.24 \pm 0.01^{\mathrm{a}}$ & $0.71 \pm 0.02^{\mathrm{a}}$ & $2.49 \pm 0.07$ & $6.44 \pm 0.10^{\mathrm{a}}$ \\
\hline \multirow{3}{*}{32} & $\mathbf{0}$ & $\mathbf{0}$ & $2.11 \pm 0.03^{b}$ & $0.61 \pm 0.02^{\mathrm{b}}$ & $2.46 \pm 0.04$ & $5.18 \pm 0.13^{\mathrm{b}}$ \\
\hline & 0.05 & $\mathbf{0}$ & $3.21 \pm 0.02^{\mathrm{a}}$ & $0.69 \pm 0.03^{\mathrm{a}}$ & $2.46 \pm 0.06$ & $6.36 \pm 0.11^{\mathrm{a}}$ \\
\hline & $\mathbf{0}$ & 0.05 & $2.10 \pm 0.05^{\mathrm{b}}$ & $0.60 \pm 0.02^{\mathrm{b}}$ & $2.46 \pm 0.05$ & $5.16 \pm 0.10^{b}$ \\
\hline \multirow{3}{*}{48} & $\mathbf{0}$ & $\mathbf{0}$ & $1.91 \pm 0.04^{\mathrm{b}}$ & $0.60 \pm 0.01^{\mathrm{b}}$ & $2.43 \pm 0.07$ & $4.94 \pm 0.12^{\mathrm{b}}$ \\
\hline & 0.05 & $\mathbf{0}$ & $3.16 \pm 0.02^{\mathrm{a}}$ & $0.69 \pm 0.02^{\mathrm{a}}$ & $2.44 \pm 0.02$ & $6.29 \pm 0.14^{\mathrm{a}}$ \\
\hline & $\mathbf{0}$ & 0.05 & $1.91 \pm 0.02^{\mathrm{b}}$ & $0.59 \pm 0.01^{\mathrm{b}}$ & $2.42 \pm 0.01$ & $4.92 \pm 0.10^{\mathrm{b}}$ \\
\hline \multirow{3}{*}{64} & $\mathbf{0}$ & $\mathbf{0}$ & $1.01 \pm 0.01^{\mathrm{c}}$ & $0.50 \pm 0.02^{\mathrm{c}}$ & $2.41 \pm 0.03$ & $3.92 \pm 0.12^{\mathrm{c}}$ \\
\hline & 0.05 & $\mathbf{0}$ & $2.16 \pm 0.03^{\mathrm{b}}$ & $0.59 \pm 0.02^{\mathrm{b}}$ & $2.42 \pm 0.01$ & $5.17 \pm 0.11^{\mathrm{b}}$ \\
\hline & $\mathbf{0}$ & 0.05 & $1.04 \pm 0.01^{\mathrm{c}}$ & $0.51 \pm 0.02^{\mathrm{c}}$ & $2.40 \pm 0.01$ & $3.95 \pm 0.10^{\mathrm{c}}$ \\
\hline \multicolumn{3}{|c|}{ CM (0) } & $3.30 \pm 0.05^{\mathrm{A}}$ & $0.75 \pm 0.03^{\mathrm{A}}$ & $2.53 \pm 0.01$ & $6.58 \pm 0.12^{A}$ \\
\hline \multicolumn{3}{|c|}{ CM (16) } & $3.29 \pm 0.04^{\mathrm{A}}$ & $0.72 \pm 0.01^{\mathrm{A}}$ & $2.50 \pm 0.03$ & $6.51 \pm 0.13^{A}$ \\
\hline \multicolumn{3}{|c|}{ CM (32) } & $2.47 \pm 0.02^{\mathrm{B}}$ & $0.63 \pm 0.03^{\mathrm{B}}$ & $2.64 \pm 0.01$ & $5.74 \pm 0.11^{\mathrm{B}}$ \\
\hline \multicolumn{3}{|c|}{ CM (48) } & $2.33 \pm 0.03^{\mathrm{B}}$ & $0.63 \pm 0.01^{\mathrm{B}}$ & $2.43 \pm 0.02$ & $5.39 \pm 0.14^{\mathrm{B}}$ \\
\hline \multirow{2}{*}{\multicolumn{3}{|c|}{ CM (64) }} & $1.40 \pm 0.01^{\mathrm{C}}$ & $0.53 \pm 0.01^{\mathrm{C}}$ & $2.41 \pm 0.01$ & $4.34 \pm 0.13$ \\
\hline & & & $2.09 \pm 0.04^{\mathrm{B}}$ & $0.61 \pm 0.01^{\mathrm{B}}$ & $2.45 \pm 0.02$ & $5.15 \pm 0.11^{\mathrm{B}}$ \\
\hline \multicolumn{3}{|c|}{ Zympex $^{\circledR} 008$} & $2.96 \pm 0.02^{\mathrm{A}}$ & $0.68 \pm 0.02^{\mathrm{A}}$ & $2.46 \pm 0.02$ & $6.10 \pm 0.12^{A}$ \\
\hline \multicolumn{3}{|c|}{ Xylam ${ }^{500}$} & $2.07 \pm 0.03^{\mathrm{B}}$ & $0.60 \pm 0.01^{\mathrm{B}}$ & $2.44 \pm 0.03$ & $5.11 \pm 0.14^{\mathrm{B}}$ \\
\hline
\end{tabular}

Means in the same column having different letters are significantly different at $\mathrm{p} \leq 0.05$.

\section{Sensory evaluation of cooked breast meat:}

Sensory evaluation values of cooked breast meat in terms of color darkness, tenderness, juiciness, chewiness, flavor by mouth (taste), odour and overall acceptance are illustrated in Tables 5. There was no significant response obtained for CM levels, enzyme supplementation or the interaction between CM level and enzymatic preparations in meat samples odour.

With respect to CM levels, judges easily distinguished the differences among the meat samples, judging that the meat sample of birds fed 64\% CM-diets had the most darkness of color as well as the least tenderness, juiciness, chewiness, flavor by mouth (taste) and overall acceptance as compared to the other treatments.

Regarding enzymatic preparations, enzyme supplementation did not cause significant change in sensory evaluation.

Fayoum J. Agric. Res. \& Dev., Vol. 21, No. 2, July, 2007 
EFFECT OF ENZYMATIC PREPARATIONS ON IMPROVEMENT... 55

Table 5

Fayoum J. Agric. Res. \& Dev., Vol. 21, No. 2, July, 2007 
With respect to the interaction between $\mathrm{CM}$ level and enzymatic preparations, adding either Zympex ${ }^{\circledR 008}$ or Xylam $^{500}$ to diet containing 16, 32, 48 or $64 \% \mathrm{CM}$ diet did not cause any significant effect in sensory evaluation as compared to the corresponding enzyme-free diets.

\section{Blood serum parameters:}

Results concerning blood serum parameters in terms of total protein (TP), albumin (Alb), globulin (Glo), Alb/Glo ratio, triglycerides (TG) and cholesterol (Cho) are presented in Table 6. There was no significant response obtained for $\mathrm{CM}$ levels, enzyme supplementation or the interaction between CM level and enzymatic preparations in TP, Alb, Glo and Alb/Glo ratio.

With respect to $\mathrm{CM}$ levels, it was noticed that feeding 16,32 or $48 \% \mathrm{CM}$ diets did not cause significant change in TG and Cho in comparison to $0 \%$ CM-diet. Increasing CM level to $64 \%$ significantly increased TG and Cho values. The present results are in harmony with the findings of Trefny $\boldsymbol{e t}$ al., (1986) who stated that blood parameters were not affected by partially or full replacement of SBM by rapeseed meal in broiler diets and Mohamed and ElHabbal, (1991) who found that plasma TP, TL and Cho values were not affected by feeding broilers on diets containing rapeseed meal. Furthermore, the increase in Cho. values observed in the present study are in good agreement with those of Hassan et al., (1992) who found that plasma lipids and Cho values increased with the increase of treated rapeseed meal in the diet and Dessouky, (1996) who revealed that total lipids and Cho values were significantly increased in case of feeding diets containing raw rapeseed meal.

Regarding enzymatic preparations, enzyme supplementation did not cause significant change in $\mathrm{TG}$ and Cho values.

With respect to the interaction between $\mathrm{CM}$ level and enzymatic preparations, adding either Zympex ${ }^{\circledR} 008$ or Xylam ${ }^{500}$ to diet containing 16, 32, 48 or $64 \%$ CM diet did not cause any significant effect in TG and Cho values as compared to the corresponding enzyme-free diets.

\section{Economical efficiency:}

Economical evaluation parameters for substituting dietary protein by $\mathrm{CM}$ protein in broiler diets in terms of feeding cost of the experimental diets, net revenue, economical efficiency $\left(\mathrm{EE}_{\mathrm{f}}\right)$ and relative economical efficiency $\left(\mathrm{REE}_{\mathrm{f}}\right.$ $\%$ ) of meat production are listed in Table 7.

The $\mathrm{REE}_{\mathrm{f}} \%$ of broilers fed the diet supplemented with enzymes was better than those fed the control diet. These results are in agreement with those reported by El-Husseiny et al., (1995) and Soliman $\boldsymbol{e t}$ al., (1996) who stated that enzyme preparations improved $\mathrm{EE}_{\mathrm{f}}$. Also, the present results are in agreement with those of Ghazalah et al., (2005) who reported that enzymes supplementation had a positive effect on reducing feed cost / $\mathrm{kg} \mathrm{BWG}$ and $\mathrm{EE}_{\mathrm{f}}$.

From the nutritional and economical point of view, it could be concluded that substituting $\mathrm{CM}$ protein up to $48 \%$ for dietary protein in both starter and finisher broiler diets supplemented with Zympex ${ }^{\circledR} 008$ enzyme product at a level of $0.05 \%$ has no detrimental effect on broiler chick's growth performance and gave the best economical efficiency. 
EFFECT OF ENZYMATIC PREPARATIONS ON IMPROVEMENT... 57

Table 6

Fayoum J. Agric. Res. \& Dev., Vol. 21, No. 2, July, 2007 
Table 7

Fayoum J. Agric. Res. \& Dev., Vol. 21, No. 2, July, 2007 
Abdallah, A.G.; M.A.M. Sayed; S.A. Ali and S. Abou El-Wafa (2003). Influence of replacing soybean meal with full-fat canola seeds or canola meal on broiler performance. The $9^{\text {th }}$ Conf. on Animal Nutrition (P. 1). Poultry, Rabbits and Fish Nutrition. Egyptain J. Nutrition and Feeds (Special Issue), Vol. 6: 110-126.

A.O.A.C. (1990), Association of Official Analytical Chemists. Official Methods of analysis $15^{\text {th }}$ Ed., published by Assoc. Office. Anal. Chem., Washington, D.C., USA.

Apata, D.F and V. Ojo, (2000). Efficacy of Trichoderma Viride enzyme complex in broiler starters fed cowpea testa-based diets. In Animal Production in New millennium. Challenges and options. Proc. Of 25th NSAP Animal Conference, Michael Okpara University of Agriculture, Umudike, p: 132-134.

Aspinall, G.O. and I.W. Cottrell. (1971). Polysaccharides of soybeans. VI. Neutral polysaccharides from cotyledon meal and chemistry of cell wall polysaccharides. Can. J. Chem. 49:1019-1022.

Atteh, J.O. and F.D. Ologbenla, (1993). Replacement of Fish meal with maggots in broiler diets. Effects on performance and nutrient retention. Nig. J. Anim. Prod., 20: 44-49.

Bacic, A.; P.J. Harris and B.A. Stone. (1988). Structure and function of plant cell walls. Pages $297-372$ in The Biochemistry of Plants. Vol 14. J. Preiss, ed. Academic Press, Inc., London.

Banerjee, G.C., (1992). Poultry, 3 edn. Oxford and IBH pub. Co. Pvt. Ltd. New Dilhi, Bombay, Calcata.

Bell, J.M. (1993). Factors affecting the nutritional value of canola meal: A review. Can. J. Anim. Sci. 73:679-697.

Butler, E.J.; A.W. Pearson and G.R. Fenwick. (1982). Problems which limit the use of rapeseed meal as a protein source in poultry diets. J. Sci. Food Agric. 33:866-875.

Castell, A.G.; W. Guenter, and F.A. Igbasan. (1996). Nutritive value of peas for nonruminant diets. Anim. Feed Sci. Technol. 60:209-227.

Chesson, A. (1993). Feed enzymes. Anim. Feed Sci. Technol. 45: 65-97.

Dale, N. (1996). Variation in feed ingredient quality: Oilseed meals. Anim. Feed Sci. Technol. 59:129-135.

Daveby, Y.D. and P. Aman. (1993). Chemical Composition of certain dehulled legume seeds and their hulls with special reference to carbohydrates. Swed. J. Agric. Res. 23:133-139.

Dessouky, M.S. (1996). Nutritional studies on rapeseed and sunflower seed as feedstuffs in broiler rations. Ph.D. Thesis, Fac. Agric., Al-Azhar Univ.

Duncan, D.B. (1955). Multiple range and multiple F- test. Biometrics, 11: 1-42.

El-Husseiny, O.M.; A.A. Ghazalah; H.M. Fayek and S.M. Abou El-Wafa (1995). Enzyme preparation, growth promoters and rumen contents in broiler diets. Egypt. Poult. Sci., 15: 205-232.

Franzoi, E.E.; F. Siewerdt; F. Rutz; P.A.R.De Brum and P.C.Gomes (2000). Carcass composition of broilers fed canola meal. Ciencia-Rural, 30: 337-342. (English Abst.).

Ghazalah, A.A.; El-Hosseiny, O.M.; Fayek, H.M. and Abou El -Wafa, S. (1994). Influence of enzyme preparations and growth promoters on broiler performance. In Proc. The $2^{\text {nd }}$ sci.conf. on Poultry, Kafr ElSheikh, Egypt, Sep.1994:140-165.

Fayoum J. Agric. Res. \& Dev., Vol. 21, No. 2, July, 2007 
Ghazalah, A.A.; A.H. Abd El-Gawad; M.S. Soliman and Amany. W. Youssef (2005). Effect of enzyme preparation on performance of broiler fed corn-soybean meal based diets. Egypt. Poult. Sci., 25: 295-316.

Hassan, F.M.; H.M.S. Shoukry and A.H. Darwish (1992). The reliability of using body weight and some biochemical and physiological variables as indicators of the adverse effects of feeding broiler chicks on rapeseed meal. Egypt. Poult. Sci., 12: 31-56.

Henry, R.F. (1974). "Clinical Chemistry Principles and Technics" $2^{\text {nd }}$ Ed., Harper and Row, Hagerstein, MD.

Hulan, H.W. and F.G.Proudfoot (1980). The nutritional value of rapeseed meal for caged layers. Can.J.Anim.Sci., 60: 139-147.

Igwebuike, J.U.; I.D. Kwari; C.O. Ubosi and N.K. Alade, (2001). Replacement value of spent sorghum grains for maize in broiler finisher diets. J. Sustain. Agri. Environ., 3: 224-233.

Kocher, A.; M. Choct; L. Morrisroe and J. Broz. (2001). Effects of enzyme supplementation on the replacement value of canola meal for soybean meal in broiler diets. Aust. J. Agric. Res. 52:447-452.

Kocher, A.; M. Choct; M.D. Porter and J. Broz. (2000). The effects of enzyme addition to broiler diets containing high concentration of canola or sunflower meal. Poult. Sci. 79:1767-1774.

Leela, A.; S.A. Al-khateeb and A.A. Al-Naeem, (2002). Response of some canola (Brassica napus, L.) varieties to drought. Final report, presented to the Deanship of Scientific Research of King Faisal University at AlHassa of Saudi Arabia.

Leeson, S. and J.D. Summers, (2001). Scott's Nutrition of the chicken, 4 ed. University Books. P. O. Box 1326, th Guelph, Ontario.

Leeson, S.; J.O. Atteh and J.D. Summers (1987). The replacement value of canola meal for soybean meal in poultry diets. Can. J. Anim. Sci., 67: 151-158.

Marsman, G.J.P.; Gruppen, H.; Vanderpoel, A.F.B.; Kwakkel R.P.; Verstegen, M.W.A and Voragen, A.G.J. (1997). The effect of thermal processing and enzyme treatments of soybean meal on growth performance, Ileal nutrients digestibility and chyme characteristics in broiler chicks. Poultry Sci., 76: 864-872.

Meng, X.; B.A. Slominski; C.M. Nyachoti; L.D. Campbell and W. Guenter. (2005). Degradation of cell wall polysaccharides by combinations of carbohydrase enzymes and their effect on nutrient utilization and broiler chicken performance. Poult. Sci. 84:37-47.

Miles R.D.; Brown, J.R.; Comer, C.W. and Oelfke, E. (1996). Influence of an enzyme and an antibiotic on broiler performance. Journal of Appl. Anim. Res.9: 2, 105-117;22 ref.

Mohamed, K.S. and M.S. El-Habbal (1991). Effect of feeding some rapeseed products on liver, heart, thyroid and plasma of broiler chickens. Egypt. Poult. Sci., 11: 303-319.

National Research Council, N.R.C. (1994). Nutrient Requirements of Poultry. $9^{\text {th }}$ Revised. Ed., National Academy of Sciences Press, Washington, D.C., USA.

NewKirk, R.W. and H.L. Classen (2002). The effects of toasting canola meal on body weight, feed conversion efficiency, and mortality in broiler chickens. Poult. Sci., 81: 815-825.

Fayoum J. Agric. Res. \& Dev., Vol. 21, No. 2, July, 2007 
EFFECT OF ENZYMATIC PREPARATIONS ON IMPROVEMENT... 61

Nworgu, F.C.; E.A. Adebowale; O.A. Oredein and A. Oni, (1999). Prospects and economics of broiler production using two plant protein sources. Trop. J. Anim. Sci., 2: 159-166.

Obi, I.U., (1990). Statistical methods of detecting differences between treatment means. 2nd edn. Snaap Press, Enugu, Nigeria.

Ojewola, G.S.; A.S. Eburuaja; F.C. Okoye; A.S. Lawal and A.H. Akinmutimi, (2003). Effect of inclusion of grasshopper meal on performance, Nutrient utilization and organ of Broiler chicken J. Sustain Agri. Environ., 5: 19-25.

Ouhida, I.; Perez, J.E; Gasa, J. and. Puchal, F. (2000). Enzymes (Bglucanase and arabinoxylanase) and/or Sepiolite supplementation and the nutritive value of maize barley based diets for broiler chicks .41: 617-624.

Salmon, R.E.; E.E.Gradiner and K.K. Klein (1981). Effect of canola (low glucosinolate rapeseed meal), protein and nutrient density on performance, carcass grade and meat yield of canola meal on sensory quality of broilers. Poult. Sci., 60: 2519-528.

Siddiqui, I.R. and P.J. Wood. (1972). Structural investigation of water-soluble rapeseed (Brassica camperestris) polysaccharides. II Acidic arabinogalactan. Carbohydr. Res. 24:1-19.

Simbaya, J.; B.A. Slominski; W. Guenter; A. Morgan and L.D. Campbell. (1996). The effects of protease and carbohydrase supplementation on the nutritive value of canola meal for poultry: In vitro and in vivo studies. Anim. Feed Sci. Technol. 61:219-234.

Singh, R.A., (1990). Poultry Production, $3^{\text {rd }}$ edition. Kalyany. Publishers, New Delhi, Ludhiana.

Slominski, B.A., and L.D. Campbell. (1990). Non-starch polysaccharides of canola meal: Quantification, digestibility in poultry and potential benefit of dietary enzyme supplementaion. J. Sci. Food Agric. 53:175-184.

Soliman, A.Z.; I. Hassan; S. Abou El-Wafa and A.G. Abdellah (1996). Utilization of high fiber sunflower meal with /without commercial enzymes or stabilized rumen extract in broiler diets. Egypt. Poult. Sci., 16: 51-67.

SPSS (1993). SPSS Statistical software Package for the social sciences. $2^{\text {nd }}$ ed. HA33-N48. McGrow-Hill, Inc., USA.

Steel, R.G.D. and J.H. Torrie (1980). Principles and procedures of statistics: A Biometrical $2^{\text {nd }}$ ed. McGraw-Hill Book Co., Inc., New York, USA

Sturkie, P.D. (1986). "Avain Physiology". $4^{\text {th }}$ ed. Springer-Verlag, New York, Inc. USA.

Summers, J.D. and M. Bedford. (1994). Canola meal and diet acid-base balance for broilers. Can. J. Anim. Sci. 74:335-339.

Summers, J.D.; S. Leeson and D. Spratt, (1988). Canola meal and egg size. Can. J. Anim. Sci., 68: 907-913.

Trefny, D.; Z. Sova; S. Petkov; A. Funcikova; L. Fukal; P. Vrabec and M.Vit (1986). Biological aspects of using the (00) rapeseed meal for broiler feeding in Czechoslovakia, Seventh European Poult. Conf., Paris (1986) Vol. 1: 477-481 (Nutr. Abst. Rev. Series B., (1988) 58:312).

Vukic Vranjes, M. and Wenk, C. (1995). Influence of dietary enzyme complex on the performance of broilers fed on diets with and without antibiotic supplementation. Bri. Poult. Sci. 36: 265-275.

Waibel, P.E.; S.L. Noll; S. Hoffbeck; Z.M. Vickers and R.E. Salmon (1992).Canola meal in diets for market turkey. Poult. Sci., 71: 1059-1066.

Fayoum J. Agric. Res. \& Dev., Vol. 21, No. 2, July, 2007 
تأثير المستحضرات الإنزيمية على تحسين الإستفادة من الطاقة الناتجة فى علاثق كتاكيت بدارى

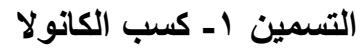

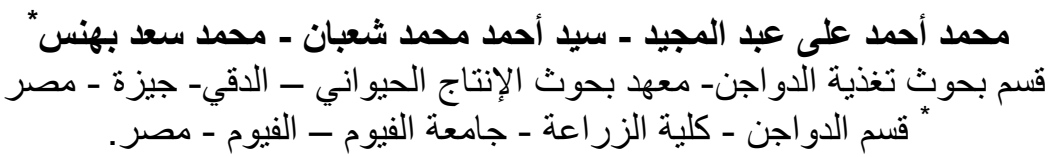

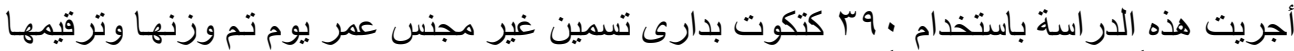

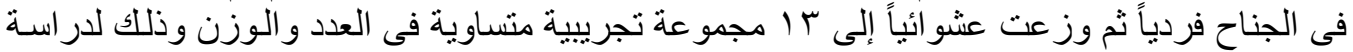

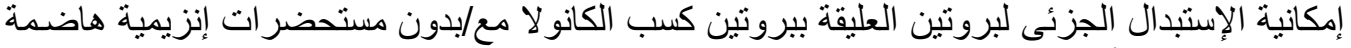
للكربو هيدرات وتأثير ذلك على آداء النمو وبعض صبرن صفات الذبيحة وكذا مكونات الدم بالإضافة إلى إجراء تقييم اقتصادى للار استة. تم تكوين عليقة بادئ و أخرى ناهى خالية من كسب الكانولا (عليقة كنترول إيجابية). كما تم تكوين

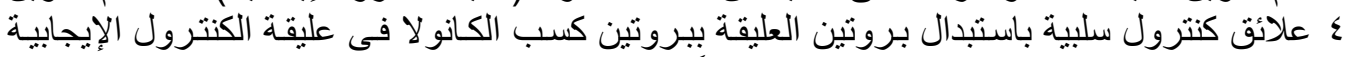

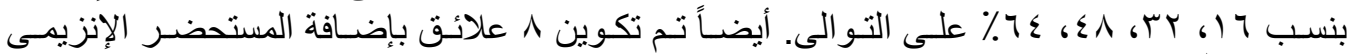

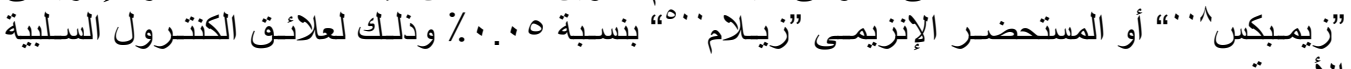
الأربعة. تم تقدير صفات أداء النمو وصفات الذيبحة وبعض مكونـات الدم كمـا تم إجراء تقييم حسى للحم الذيحة الدطبو خ وكذا تقييم اقتصادى للادراسة.

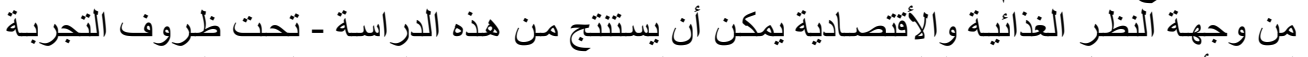

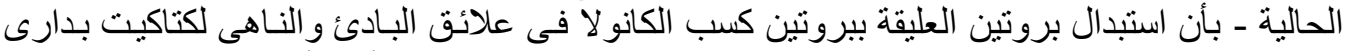

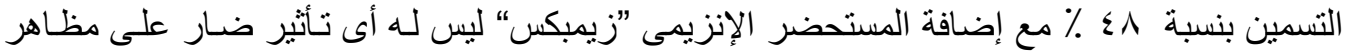
النمو كما أعطت أعطت أفضل كفاءة أقتصادية.

Fayoum J. Agric. Res. \& Dev., Vol. 21, No. 2, July, 2007 